Original Research Paper

\title{
Study of the Efficiency of the Entomophage Habrobracon Hebetor Say to Control the Number of Etiella zinckenella Tr. on Soybean Crops
}

\author{
Irina Sergeevna Agasyeva, Maria Vladimirovna Nefedova* and Anton Sergeevich Nastasiy \\ Federal State Budgetary Scientific Institution “Federal Research Centre of Biological Plant Protection”, Krasnodar, Russia
}

\author{
Article history \\ Received: 13-11-2020 \\ Revised: 19-02-2021 \\ Accepted: 26-02-2021 \\ Corresponding Author: \\ Maria Vladimirovna Nefedova \\ Federal State Budgetary \\ Scientific Institution "Federal \\ Research Centre of Biological \\ Plant Protection", Krasnodar, \\ Russia \\ Email: dollkasneba@yandex.ru
}

\begin{abstract}
Soybean is a valuable crop in many countries of the world. The world sowing area of soybeans is about 100 million hectares. It is grown in the main agricultural regions of 90 countries. To obtain a stable yield level, it is necessary to take into account the activity of arthropod organisms, both harmful and beneficial. The species composition of arthropods of soybean agro enosis in the central zone of Krasnodar Krai has been determined. 227 species of insects and 2 species of mites were identified, including 98 species of phytophages damaging soybeans and 129 species of entomophages. These insects are distributed in 9 orders, 51 families. The most dangerous phytophages of soybeans account for $9.3 \%$ of the total number of species. Cotton moth (Helicoverpa armigera Hbn), limabean pod borer (Etiella zinckenella Tr.) and common spider mite (Tetranychus urticae Koch) are widescalephytophages. We assessed the biological efficacy of the ectoparasite Habrobracon hebetor Say against E. zinckenella, this approach does not provide for total destruction, but regulation of the number by restoring the natural mechanisms of regulation. Artificial breeding of the entomophage and its early introduction into soybean cenosis allows us to effectively control the number of E. zinckenella. We described the prospects of using entomohages in green farming technologies.
\end{abstract}

Keywords: Species Composition, Biological Protection, Biotechnology, Habrobracon Hebetor Say

\section{Introduction}

By its natural and climatic conditions, the south of Russia is the most favorable place for soybean cultivation. Over the past 10 years, its sown areas range from 150 to 170 thousand hectares.

The main reason that caused the rapid growth of soybean production is the unique chemical composition of its grain (Hartman et al., 2011; Didorenko et al., 2016). Soybean seeds accumulate $35-45 \%$ of protein and $20-25 \%$ of oil (Gaur and Mogalapu, 2018). Currently, the popularity of soybean as a crop is growing due to its high environmental friendliness. It is of great interest in the farm rotation in comparison with other crops, because, due to its ability to bind atmospheric nitrogen, soybean significantly contributes to the environment. There is additional plant nutrition with nitrogen due to the binding of atmospheric nitrogen and the absorption of mineral nitrogen from soil. As a result, there is no need to introduce synthetic nitrogen fertilizers for soybean, which, as a rule, can cause pollution of groundwater. Moreover, if cereals are cultivated after soybeans, there is a yield increase and a reduction in nitrogen fertilizers amount.

An important fact is that the range of soybean pests in the European part of Russia is in its infancy and the sowing of soybean crops by phytophages and their parasites occurs solely due to migration flows from the surrounding biocenoses, which makes phytosanitary monitoring necessary not only for the target crop, but also for the related ecosystems (Piven and Bushneva, 2006).

Soybean is damaged by many types of arthropods (Formentini et al., 2015), but the richest and most specialized complex of its pests comes from East Asia. In areas where soybean is a new crop, there is a constant transition to soybean of a number of native phytophage species. The process of transition of local species to the use of a new food resource has not been completed and a number of niches have not been taken by pests yet, which 
requires regular study of emerging species diversity (Heinrichs and Muniappan, 2018).

The unsaturation of the phytophage complex in soybean in the North Caucasus creates the threat of the transition of new harmful species to it, which requires constant study and refinement of their species composition. The set of entomophages of soybean cenosis, their role in controlling the number of pests and the importance of the crop as a reserve of useful species for the entire agroecosystem have not been thoroughly studied.

In the south of Russia, there is a direct correlation between the growth of sown areas of soybeans and an increase in the species composition and number of phytophages (Devyatkin and Vasilenko, 2017; Piven' and Bushneva, 2007; Saenko and Bushneva, 2019).

We should mention that recently plant protection against pests has lost its complexity, regularity and reduced to the predominant use of pyrethroid and organophosphorus products (Bortolotto et al., 2015; Dolzhenko, 2009). Consequently, there is the depletion of the entomofauna, the formation of insecticide-resistant pest populations, the pollution of the agricultural sphere by their residues and the increase in costs, often overtaking the cost of a protected crop (Wahyudi et al., 2019). In particular, in the North Caucasus region under extremely unfavorable phytosanitary conditions, emergency situations occur annually with the spread and harmfulness of Elateridae, Helicoverpa armigera Hbn, Etiella zenckeneila Tr. and other pests (Srinivasan, 2014; Fourie et al., 2015; Lima et al., 2017). To a large extent, the increase in their number is associated with the formation of resistant populations characterized by increased viability and harmfulness (Heinrichs and Muniappan, 2018; Murithi et al., 2019).

According to recent observations, E. zinckenella is frequently found among the important economic pests of soybean (Agasieva et al., 2015; Kuswantoro et al., 2017). Due to insufficient knowledge of the issue of environmentally safe protection of soybeans from this pest, there is a need to research to determine the possibility of using Habrobracon hebetor Say as a biological agent. The aim of this study is to study trophic connections and useful activities of intruded (by the example of an ectoparasitoid $H$. hebetor) and natural populations of entomophages, which determine the restoration of the mechanisms of natural biocenotic regulation. It is assumed that the release of entomophage propagated in the laboratory, the cancellation of chemical treatments, can stimulate the restoration of mechanisms of natural biocenotic regulation and will contribute to the activity of native natural entomophages, which will protect soybean crops from the pest.

\section{Materials and Methods}

The studies were conducted basely at the laboratory of the State collection of enthomoacariphages and initial evaluation of biological plant protection products of Federal Research Centre of Biological Plant Protection (FRCBPP), Krasnodar, Russia.

To determine the species composition of insects and mites, identify useful and harmful species, we collected arthropods in 2016-2018 at the experimental field of soybean, Federal State Budgetary Scientific Institution "Federal Research Centre of Biological Plant Protection" (FSBSI FRCBPP) on the area of 3 hectares, the variety Arleta and in Agronova LLC, Labinskiy district of Krasnodar region on certified organic standard cultivar Vilana on the area of 3 hectares in 2018-2019. Arthropods were captured using an entomological net, Malez and Merike traps. We calculated the indicator of dominant species as the ratio of the number of insects of a particular species to the sum of all insect species in all samples.

Taxonomic identification of insects was carried out using determinants and comparative entomological collections (Akhremovich et al., 1976; Velikan et al., 1983).

For laboratory cultivation of the parent populations of the ectoparasite $H$. hebetor, we used the caterpillars Ephestia cuhniellia Zeller and Galleria mellonela L. as host insects. Caterpillars were placed in 0.5-liter glass jars and $H$. hebetor was introduced. The jars were tightened with a calico cloth with a cotton swab moistened with a $20 \%$ sugar solution for feeding ectoparasite. Insect breeding was carried out in a climatic chamber (Binder 9020-0343 (KMF-240)) at a temperature of $26-28^{\circ} \mathrm{C}$, relative humidity of $70 \%$ and a photoperiod of at least 16 h. 11-13 days after infection, the start of the filial generation imago begins.

To determine the age of the pest caterpillars that will be most successfully infected by $H$. hebetor, we carried out a series of laboratory experiments. Seventy $E$. zinckenella caterpillars of various ages (younger, middle and older) were placed in $0.5 \mathrm{~L}$ glass containers. Then, using an exhauster, we placed 30 females of $H$. hebetor in each container. Next, we observed the development of ectoparasite, counted paralyzed caterpillars and counted the number of cocoons formed. The experiment was repeated four times.

Statistical data processing was performed using the Statistica 13.0 software package with the Duncan test.

\section{Results}

As a result of the research we identified 227 species of insects and 2 species of mites, including 98 species of phytophages (43.2\% of the total fauna) that damage soy and 129 species of entomophages $(56.8 \%$ of the total 
fauna) on soybean crops. These insects are distributed in 9 orders, 51 families.

The most numerous among the 98 species of phytophages that damage soy, are representatives of the order Hemiptera-29 species. They comprise $12.8 \%$ of the total fauna or $29.6 \%$ of the harmful fauna (Fig. 1). Representatives of the order Lepidoptera are slightly inferior to them-28 species (12.3\% of the total fauna and $28.6 \%$ of the harmful fauna). The number of representatives of the orders Coleoptera, Orthoptera and Homoptera is 26, 12 and 11 species, or $11.5 ; 5.3$ and $4.8 \%$ of the total fauna and 26.5, 12.2 and $11.2 \%$ of the harmful fauna, respectively. Representatives of the Thysanoptera order account for only $1.9 \%$ of the total and $4.1 \%$ of the harmful fauna (Fig. 1).

The most economically significant soybean pests account for $9.3 \%$ of the total species composition. At the time of observation permanent pests were: Bugs of Nabidae, Miridae and Pentatomidae families, Lepidoptera, H. armigera, Heliothis viriplaca Huf., E. zinckenella. As can be seen from Fig. 1, the main share in the collections (106 species) is made up of parasitic Hymenoptera from the families Ichneumonidae, Braconidae, Aphidiidae, Eurytomidae, Ormyridae, Pteromalidae, Encyrtidae, Eupelmidae, Eulophidae, Elasmidae, Scelionidae, Platygastridae,
We found out that the formation of the entomoacarifauna of soybean cenosis and the number of species are closely related to weather conditions, phases of plant development, variety, placement of fields in crop rotation (spatial isolation) and the presence of mixed soybean crops with other crops and with the level of pesticide load. With the cancellation of chemical treatments, the ratio of harmful and useful species changes in favor of the last (Table 1).

The abolition of chemical treatments had a particularly positive effect on the species diversity of parasitic insects. So in the first year of research, 203 species were discovered, of which $44.8 \%$ were Hymenoptera parasites. In the second year of research, out of 213 discovered species, the number of Hymenoptera increased to $46.0 \%$. As already shown above, in the third year of research, 227 species were found in the agrocenosis of soybeans, 106 of which are represented by parasites, which is $46.7 \%$.

The widespread use of pesticides in agrocenoses results in profound changes in the composition and structure of the pest complex, which often contributes to the transformation of minor (potential) pests into economically significant ones. Many of them periodically give outbreaks of mass breeding. These phytophages include E. zinckenella, which can cause yield losses up to $60-93 \%$.

Trichogrammatidaеи Chrysididae.

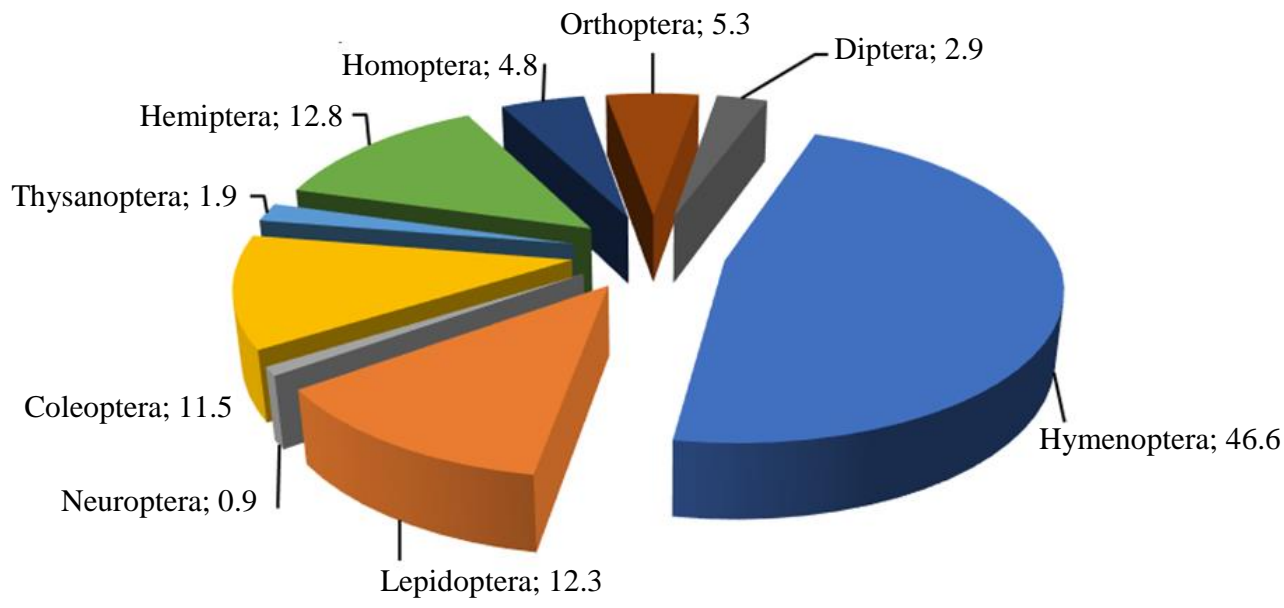

Fig. 1: The ratio of insect species of soybean agrocenosis

Table 1: The ratio of phytophages and entomophages of soybean cenosis

Insects identified in the soybean cenosis \%

\begin{tabular}{|c|c|c|c|c|}
\hline \multirow[b]{3}{*}{ Years } & \multirow[b]{3}{*}{ Total species } & \multicolumn{3}{|c|}{ Insects identified in the soybean cenosis \% } \\
\hline & & \multirow[b]{2}{*}{ Phytophages } & \multicolumn{2}{|c|}{ Entomophages } \\
\hline & & & Predators & Parasites \\
\hline 2016 & 203 & 45.8 & 9.4 & 44.8 \\
\hline 2017 & 213 & 44.4 & 9.4 & 46.0 \\
\hline 2018 & 227 & 43.2 & 10.1 & 46.7 \\
\hline
\end{tabular}


As a bioagent capable of reducing the chemical load on soybean agrocenoses, we selected $H$. hebetor, known as a parasite of more than 60 species of lepidopteran pests. The natural $H$. hebetor population is able to reduce the caterpillars number of Ostrinia nubilalis Hüb up to $22 \%$, Lacanobia oleracea L.-up to $35 \%, H$. armigera -up to $45 \%$, Autographa gamma L. -up to $30 \%$.

The insects of $H$. hebetor we caught in nature comply with the species standards. The body length of the female $H$. hebetor is $2.5-3 \mathrm{~mm}$, the male is $2-2.7 \mathrm{~mm}$. Color varies from light yellow to brown. The eyes are black. Antennae are 14-18-segmented. The ovipositor is shorter or equal to the length of the abdomen. Egg is $0.5-0.65 \mathrm{~mm}$. The larva has 3 ages. Its length is $0.65-3.5 \mathrm{~mm}$., depending on age.

It was found that the entomophage hibernates at the imago stage. In April-May, at a temperature of $15^{\circ} \mathrm{C}$, it emerges and concentrates on flowering weeds (dandelion, shepherd's bag, gallows, wild radish, etc.), fruit crops and vineyards. Here, $H$. hebetor eats nectar and pollen of flowers, mates and when potential hosts appear on crops, flies there.

The parasite exhibits its maximum activity at an air temperature of $25-30^{\circ} \mathrm{C}$ on sunny calm days. The male $H$. hebetor are polygamous, the females are monogamous. When searching for a host, the parasite females are guided by smells. Initially, they are attracted to the host plant and then the caterpillars and their excrement. The combination of several plants and host insects plays an important role in attracting the parasite. The normal vital activity of female $H$. hebetor is provided by carbohydrate feeding and the hemolymph nutrition of host insects.

To determine the possibility of practical application of $H$. hebetor, we carried out a series of laboratory experiments. As a result of the experiments, it was found that the parasite infects no more than $4 \%$ younger age caterpillars of E. zinckenella and it finds the most attractive the caterpillars of middle and older ages.

According to the experimental data, the share of paralyzed caterpillars varied from 48 to $72 \%$ with an average of $54.8 \%$. At the same time, the parasite left viable offspring on $85 \%$ of paralyzed caterpillars, which in the future is able to restrain the phytophage.

Experimental release of $H$. hebetor against the second generation of E. Zinckenella, which is developing on soybean was carried out at the end of flowering-the beginning of the formation of beans at the rate of 1500 individuals/ha.

The released parasite actively propagated itself and during the development of one generation of $E$. zinckenella two generations of the parasite developed. Propagating, ectoparasite upon reaching a certain number, significantly suppressed the pest. The next release strengthened the natural population and the total activity of the bioagent reached $78 \%$.

\section{Discussion}

The study of the arthropods species composition in soybean agrocenosis made it possible to identify parasitic insects that feed on different stages of E. zinckenella reduce its abundance and harmfulness. Of particular importance in the regulation of the size of E. zinckenella is played by representatives of the families Ichneumonidae, Braconidae, Eurytomidae, Pteromalidae, Eupelmidae, Eulophidae, Elasmidae, Scelionidae and Trichogrammatidae.

Due to the biological peculiarities of the $H$. hebetor in the choice of priority caterpillars of middle and older ages, the likelihood of competition between the H. hebetor and the native beneficial insects species of the families Scelionidae, Trichogrammatidae is excluded, which increases the efficiency of entomophages.

The methods and timing of seasonal colonization of entomophages are crucial in the biological control of pests.

Currently, the protection of legumes against $E$. zinckenella provides for 2-3 times application of insecticides, due to the extension of the flying period of butterflies (therefore, the period of egg laying) and the secretive lifestyle of the harmful stage-caterpillars of all ages (Permana et al., 2012; Naroz et al., 2019).

Taking into account modern agroecological requirements for integrated plant protection systems, technologies for the operational control of pest numbers aimed at restoring the processes of self-regulation of agrocenoses should be used (Bueno et al., 2013; Sanin, 2017; Wahyudi et al., 2019; Bueno et al., 2020).

The bioecological characteristics of $H$. hebetor is formed in natural conditions and is related to the specific environmental features of agroecosystems. Deviations from the species standard can be caused by: Climatic conditions, a set of cultivated, wild-growing plants and natural hosts inhabiting them. Fertility, search activity, the number of $H$. hebetor generations are determined by the density of populations and the number of generations of host insects, the timing and duration of flowering of the crop. Therefore, the local ecotype is of practical value, which was caught in order to clarify its bioecological features and the possibility of practical application for the biological control of lima-bean pod borer.

Like many ectoparasites developing on insect bodies, $H$. hebet or are characterized by: Parasitizationon lurking hosts, their paralysis, high development rate of larvae and wide food chain. When a target caterpillar is found, the female paralyzes it, introducing the secret of poisonous glands into it and then lays eggs on the body, creating the basis for further reproduction of the entomophage. 
The release of ectoparasite made it possible to cancel chemical treatments, which contributed to the preservation of natural parasitic insects and enhance the protective effect.

\section{Conclusion}

The species composition of soybean arthropods includes 227 insect species and 2 mite species, including 98 species of phytophages $(43.2 \%$ of the total fauna) that damage soybean and 129 species of entomophages (or $56.8 \%$ of the total fauna). These insects are distributed in 9 orders, 51 families. Among them, the most important in the regulation of the $E$. zinckenella population are Ichneumonidae, Braconidae, Eurytomidae, Pteromalidae, Eupelmidae, Eulophidae, Elasmidae, Scelionidaeи Trichogrammatidae.

$H$. hebetor will most successfully infect older and middle-aged E. zinckenella caterpillars, leaving viable offspring for $85 \%$ of paralyzed caterpillars, which enhances the overall efficiency with natural entomophages.

Including $H$. hebetor ectoparasite in the system of ecofriendly protection of soybeans against pests can be an alternative to chemical insecticides. When used to control lima-bean pod borer this approach does not provide for total destruction, but regulation of the number by restoring the natural mechanisms of regulation.

\section{Acknowledgment}

Studies were carried out in accordance with State Assignment \# 075-00376-19-00 of the Ministry of Science and Higher Education of the Russian Federation as part of research on the topic \# 0686-2019-0009.

\section{Authors Contribution}

Irina Sergeevna Agasyeva: Designing an experiment, conducting an experiment, writing an article.

Maria Vladimirovna Nefedova: Data analysis, article writing.

Anton Sergeevich Nastasiy: Conducting an experiment, analyzing data.

\section{References}

Agasieva, I. S., Ismailov, V. Ya., Fedorenko, E. V., \& Nefedova, M. V. (2015). Development of a biological soybean pest protection system using entomoacariphages. VII Materials of the international scientific-ractical conference: Agrotechnical method of plant protection from harmful organisms, June 15-19, 2015, Krasnodar, Russia, Kuban State Agrarian University, Krasnodar, pp: 8-11. ISBN: 978-5-94672-949-9
Akhremovich, M. B., Batiashvili, I. D., \&Bei-Bienko, G. Y. A. (1976). Keys to agricultural pests for damage to cultivated plants. Kolos. Leningrad, pp: 696. http://www.bibliolink.ru/publ/9-1-0-55

Bortolotto, O. C., Pomari-Fernandes, A., Bueno, R. D. F., Bueno, A. D. F., da Kruz, Y. K. S., Queiroz, A. P., ... \& Ferreira, R. B. (2015). The use of soybean integrated pest management in Brazil: a review. EmbrapaSoja-Artigoemperiódicoindexado

(ALICE). http://dx.doi.org/10.33158/ASB.2015v1i1p25

Bueno, A. D. F., Panizzi, A. R., Hunt, T. E., Dourado, P. M., Pitta, R. M., \& Gonçalves, J. (2020). Challenges for Adoption of Integrated Pest Management (IPM): the Soybean Example. Neotropical Entomology, 1-16. https://doi.org/10.1007/s13744-020-00792-9

Bueno, A. F., Paula-Moraes, S. V., Gazzoni, D. L., \& Pomari, A. F. (2013). Economic thresholds in soybean-integrated pest management: old concepts, current adoption and adequacy. Neotropical Entomology, 42(5), 439-447. https://doi.org/10.1007/s13744-013-0167-8

Devyatkin, A. M., \& Vasilenko, A. I. (2017). Pests and entomophages in soybean crops in the central zone of the Krasnodar Territory. In the collection: agrotechnical method of protecting plants from harmful organisms. Materials of the VIII International Scientific and Practical Conference, dedicated to the 95th anniversary of the Kuban State Agrarian University, pp: 126-128. https://elibrary.ru/item.asp?id=35612250

Didorenko, S. V., Alenkhanovna, Z. A., Sidorik, I. V., Abuglieva, A. I., Kudaibergenov, M. S., \&Iskakov, A. R. (2016). Diversification of Crop Production by Means of Spreading Soybeans to the Northern Regions of the Republic of Kazakhstan. Biosciences Biotechnology Research Asia, 13(1), 23. http://dx.doi.org/10.13005/bbra/1998

Dolzhenko, V. I. (2009). Guidelines for registration tests of insecticides, acaricides, molluscicides and rodenticides in agriculture. Saint-Petersburg, LLC SPB SRP PAVEL VOG.

Formentini, A. C., Sosa-Gómez, D. R., Paula-Moraes, S. V. D., Barros, N. M. D., \& Specht, A. (2015). Lepidoptera (Insecta) associated with soybean in Argentina, Brazil, Chile and Uruguay. Ciência Rural, 45(12), 2113-2120. https://doi.org/10.1590/0103-8478cr20141258

Fourie, H., De Waele, D., Mc Donald, A. H., Mienie, C., Marais, M., \& De Beer, A. (2015). Nematode pests threatening soybean production in South Africa, with reference to Meloidogyne. South African Journal of Science, 111(9-10), 01-09. https://doi.org/10.17159/sajs.2015/20140212 
Gaur, N., \& Mogalapu, S. (2018). Pests of Soybean. In Pests and Their Management (pp. 137-162). Springer, Singapore. https://doi.org/10.1007/978-981-10-8687-8

Hartman, G. L., West, E. D., \& Herman, T. K. (2011). Crops that feed the World 2. Soybean-worldwide production, use and constraints caused by pathogens and pests. Food Security, 3(1), 5-17. https://doi.org/10.1007/s12571-010-0108-x

Heinrichs, E. A., \& Muniappan, R. (2018). Integrated pest management for tropical crops: Soybeans. CAB Revise, 13(055), 1-44. https://doi.org/10.1079/PAVSNNR201813055

Kuswantoro, H., Bayu, M. S., Baliadi, Y., \&Tengkano, W. (2017). Resistance of advanced soybean lines to pod borrer (Etiellazinckenella). Biosaintifika: Journal of Biology \& Biology Education, 9(2), 317-324. https://doi.org/10.15294/biosaintifika.v9i2.7895

Lima, F. S., Correa, V. R., Nogueira, S. R., \& Santos, P. R. (2017). Nematodes affecting soybean and sustainable practices for their management. Soybean-The Basis of Yield, Biomass and Productivity, 3, 95-110. https://doi.org/10.5772/67030

Murithi, H., Wosula, E., Lagos-Kutz, D., \& Hartman, G. (2019). The State of Soybean in Africa: Soybean Pests. Farmdoc Daily, 9(199). https://doi.org/10.18697/ajfand.88.SILFarmDoc09

Naroz, M. H., Abd El-Rahman, S. F., \& Abdel-Wahab, E. I. (2019). The relationship between agronomic characters of certain soybean varieties and infestation resistance of Etiellazinckenella (Lepidoptera: Pyralidae) under natural conditions. Journal of Entomology and Zoology Studies, $\quad 7(2), \quad 69-77$. https://www.entomoljournal.com/archives/2019/vol7is sue2/PartB/7-1-267-214.pdf

Permana, A. D., Johari, A., Putra, R. E., Sastrodihardjo, S., \& Ahmad, I. (2012). The influence of trichome characters of soybean (Glycine max Merrill) on oviposition preference of soybean pod borer Etiellazinckenella Treitschke (Lepidoptera: Pyralidae) in Indonesia. Journal of Entomology and Nematology, 4(3), 15-21. https://doi.org/10.5897/JEN.9000038
Piven, V. T., \& Bushneva, N. A. (2006). Soybean Phytophabes and Measures to Combat harmful species. Diseases and pests of oil crops (collection of scientific works), 2006, Krasnodar, Russia, Federal Research Center $<<$ All-Russia Research Institute of oil crops by V.S. Pustovoit $>, \quad$ pp: 127-131. https://www.elibrary.ru/item.aspid=35229507\&pff $=1$

Piven', V. T., \& Bushneva, N. A. (2007). Rationale for the protection of soybeans from lima-bean pod borer and cotton bollworm Oilseeds. Scientific and technical bulletin of the All-Russian Scientific Research Institute of Oilseeds, 2(137), 98-103. http://journaloil-crops.ru/vypusk-2-137/

Saenko, G. M., \& Bushneva, N. A. (2019). Monitoring of diseases and pests of soybeans in the Krasnodar region. In the collection: Collection of materials of the All-Russian (national) scientific-practical conference. Materials of the All-Russian (national) scientific-practical conference dedicated to the 100th anniversary of the birth of S. I. Leontiev. Omsk State Agrarian University named after P.A. Stolypin, pp: 484-488. https://elibrary.ru/item.asp?id=37611861

Sanin, S. S. (2017). The strategy of modern plant protection at intensive grain production. VestnikOrelGAU, 3, 35-39. http://dx.doi.org/10.15217/48484

Srinivasan, R. (2014). Insect and mite pests on vegetable legumes: a field guide for identification and management (No. BOOK). AVRDC-The World Vegetable Center. https:// avrdc.org/download/publications/manuals/eb0228 .pdf

Velikan, B. C., Golub, V. B., \& Gur'eva, E. L. (1983). Keys to harmful and beneficial insects and mites of annual and perennial grasses and legumes in the USSR. Kolos. Leningrad. Department, p. 272. https://elibrary.ru/item.asp?id=23080825

Wahyudi, A., Priyanto, J., Afrista, R., Kurniati, D., Astuti, R. I., \& Akhdiya, A. (2019). Plant growth promoting activity of actinomycetes isolated from Soybean Rhizosphere. Online Journal of Biological Sciences, 19 (1), 1-8. https://doi.org/10.3844/ojbsci.2019.1.8 